\title{
Amplification of Capturing of Euro zone Crises on PIIGS Nations Through Dummy Variables Approach
}

\author{
Effulgence \\ Vol. 17, No. 1 \\ January - June 2019 \\ Rukmini Devi Institute of Advanced Studies \\ E-mail : effulgence@rdias.ac.in, Website : www.rdias.ac.in \\ http://effulgence.rdias.ac.in/user/default.aspx \\ https://dx.doi.org/10.33601/effulgence.rdias/v17/i1/2019/28-45
}

\author{
Dr. Anjala Kalsie ${ }^{1} \backslash \Delta$ \\ Ms. Jaya Pandey ${ }^{2}$
}

Abstract

After subprime crisis the Euro-zone crisis emerged and has taken many of European countries in its effect quickly. To get the stimulus of the euro crisis on PIIGS economies it is essential to study the patterns of various selected variables. The objective of this paper is to identify various variables that were severally and significantly touched during the crisis for each of the PIIGS nations. In order to know the trend of the various variables the total time period is divided into three periods namely pre crises, during crisis and post crisis period. The period of crisis emergence is taken as 2008-09. The data set was normalized before applying dummy variables exercise for capturing structural break. Spain is the most affected country among PIIGS nations both during the crisis and after the crisis. The least affected country in the post crisis period is either Ireland or Italy.

Keywords: Euro-zone, PIIGS, Dummy Variables, Structural Break.

JEL Classification: E41, E44, G01,

\section{INTRODUCTION}

A fter subprime crisis the Eurozone crisis emerged and has taken many of European countries in its effect quickly. It is interesting to know the governing force of this crisis and its sudden diffusion. Eurozone is a group of European Union countries sharing a common currency and central bank. There may be so many possible reasons of crisis onr can assume and guess. Moving systematically to know root causes of the crisis, a thorough theoretical study of available literature related to the topic has been done and achieved many economic factors responsible for crisis.

In the present paper the analysis of those Variables are to be done empirically with the help of structural break analysis. In present paper all those theoretically observed Variables would be judged as Variables of crisis. The Euro zone crisis has spread drastically and in infectious way to many of the

1. Assistant Professor, Faculty of Management Studies, University of Delhi, kalsieanjala@gmail.com

2. Research Scholar, University of Delhi 
European economies. To get the complete root causes of the crisis the study has been done at different levels. Variables thus accumulated in various stages have been brought forward for further analysis in this paper.

\section{LITERATURE REVIEW}

Many researches are already done on different aspects of Euro crisis, its underlying reasons and impacts. Some of that previous literature is reviewed here in context of starting time of the crisis and its havoc thereafter on PIIGS nations. In context of the objective of present paper following literature are briefed here.

As per Filoso and Panico et al. (2016) the global financial crisis began in May 2010; when the assistance to Greece was approved. The structural breaks in the bond market of three of the PIIGS nations; namely Greece, Spain and Italy detected for a range of break points starting from 2009to 2014. The structural break is exactly detected on 10-year maturity long term bonds interest rate. The data is taken on daily interval.

Kaplanoglou and Rapanos (2012) confirm starting point of Euro crisis in Greece in November 2009 because of outbreak of fiscal imbalances and concluded Greek crisis as a fiscal crisis.

Ahmad and Bhanumurthy et al. (2014) extended the line of research by defining the starting and end point of the Euro zone crisis as 19 October 2009 to 31 January 2012 respectively. Lekakis and Kousis (2013) have also taken the US subprime crisis 2008 as the basic root of the Greek crisis. Kretsos (2011) has taken year 2009 as the year of expansion of economic crisis. Pereira and Pedro (2015) gave role of the "inner" real exchange rates; as basic reasons of the crisis. Euro is responsible for the internal asymmetry and imbalances with in the Euro zone. The paper declared the stagnant position of the Eurozone since 2009 because of this "exchange rate crisis". Moreover, the crisis was primarily economic and financial in description, but after a certain point, the financial problem was soundly taken care by the ECB, but the economic difficulty coupled with imbalanced internal exchange rates rests.

Gocaj and Meunier (2013) explained early 2010 was the time of crisis eruption from Greece in the form of speculation in the whole Euro area countries. Garbellini and Marelli et al.(2014) have taken years 2011-12 of the Euro zone sovereign debt crisis. OteroIglesias (2011) stated starting of Eurozone crisis in 2010. Vlamis (2013) stated the starting point of the Greek crisis as October 2009.

Angela Merkel's discourse profile during the economic crisis and the European crisis policies" the author Puhringer (2015) also validates the starting of the Euro crisis in the year 2008. This paper mentions Merkel blames on financial market and imprudent conduct of some market players responsible for the crisis.

According to Chionis and Pragidiset al. (2016) the Greek crisis reportedly started with the noticeable disorders in the Greek bond's market begin on 10 October 2009 following the declaration of revision of its budget deficit. This resulted in putting all of the PIIGS nations in vulnerable condition. During the crisis budget deficit, unemployment, debt to GDP ratio and inflation were the main accountable variables for the performance of Greek 10-year sovereign bond yield.

Mugarura (2016) reported the starting of the Greek debt crisis in 2009 and it separated the Eurozone members in two separate groups. Tracy (2011) addressed the Eurozone crisis as 2010 Greek financial crisis. Collins and Gavron (2004) blamed inflation level and lagged level of financial liquidity of a country are main drivers of contagion from another country.

Stock hammer and Onaran (2012) the crisis is the consequence of economic strategies that have designed to focus on financial integration and labour 
market flexibility. Prorokowski (2011) pursues to expose up new vistas for crisis recovery programme. It finds out that in crisis recovery measures government's help or offers play very effective role rather than engaging public funds to crisis-affected countries. This is particularly the case of Russia and some other countries.

Barth and Prabha et al. (2012) linked sovereign risk to the banking sector factors. The countries having high porting of banking assets as compared to their GDP; found to have high correlation between sovereign risk and banking factors. In other words, banking factors are mainly responsible for the sovereign crisis. Valverde and Benink et al. (2015) reported the increasing harshness of the Euro zone crisis during 2010 in some peripheral countries of the zone, especially.

\section{OBJECTIVE AND METHODOLOGY}

To get the stimulus of the euro crisis on PIIGS economies it is essential to study the patterns of various selected variables. The objective of this paper is to identify various variables that were severally and significantly effected during the Eurozone crisis for each of the PIIGS nations. In order to know the trend of the various variables the total time period is divided into three periods namely pre crises (2001 to 2007), during crisis (2008-09) and post crisis period (2010 to 2015). The performance of the selected variables will be helpful for one to understand and detect the responsible variables of the crisis.
The null hypothesis in this analysis is that there is no structural break in the variables in all the three crises periods namely pre crises, during crises and post crises period. The alternate hypothesis is that there is presence of structural breaks in the variables chosen. $\mathbf{H 0}=$ Variables are not having any structural break during the given duration (2001 to 2015); and

H1 = Variables are having any structural break during the given duration (2001 to 2015)

\section{Data Source}

The variables were elected after extensive literature review. In selecting the variables, which is to be tested for structural break; the notion is to choose as many variables as possible, which is mentioned in the literature review. Thus all the variables which are used in existing studies (whether empirical or theoretical) are taken into account.

Total 113 Variables were taken into account after the literature review to represent causes of crisis. These 113 variables were categorized into four broad categories tabulated in Table 1 . The data were taken from World Bank (Worldwide Governance Indicator and World Development Indicator), Central Statistics Office, Ireland, FRED Economic Data and OECD Statistics. Variables are mostly taken as percentage of GDP, except for few variables which are in indices; some are ranking variables, some are growth variables and some banking variables are taken as ratio variables in the study.

Table 1 : Total Variables Collected Arranged in Four Broad Categories

\begin{tabular}{|l|l|}
\hline Macro-economic Variables & Financial Variables \\
\hline 1. GDP in Current US\$ & $\begin{array}{l}\text { 1. Net Investment in Nonfinancial Assets } \\
(\% \text { of GDP })\end{array}$ \\
\hline 2. GDP (in constant LCU) & $\begin{array}{l}\text { 2. Corporate Bond Issuance Volume to } \\
\text { GDP }(\%)\end{array}$ \\
\hline 3. GDP (in current LCU) & 3. Total Factoring Volume to GDP (\%) \\
\hline
\end{tabular}




\begin{tabular}{|c|c|}
\hline 4. GDP per Capita (in \% of GDP) & $\begin{array}{l}\text { 4. Provisions to Nonperforming Loans } \\
(\%)\end{array}$ \\
\hline 5. GDP Annual Growth (in \%) & 5. Financial System Deposits to GDP (\%) \\
\hline 6. GNI per Capita in $\%$ of GDP & 6. Liquid Liabilities to GDP (\%) \\
\hline 7. CPI Inflation & 7. Insurance Company Assets to GDP (\%) \\
\hline 8. Inflation in GDP Deflator & $\begin{array}{l}\text { 8. Nonlife Insurance Premium Volume to } \\
\text { GDP }(\%)\end{array}$ \\
\hline $\begin{array}{l}\text { 9. Cash Surplus/Deficit (\% of GDP), Percent of } \\
\text { GDP, Annual, Not Seasonally Adjusted }\end{array}$ & $\begin{array}{l}\text { 9. Domestic Credit Provided by Financial } \\
\text { Sector }(\% \text { of GDP) }\end{array}$ \\
\hline 10. CA Balance (in \% of GDP) & $\begin{array}{l}\text { 10. Credits to Government and State } \\
\text { Owned Enterprises to GDP (\%) }\end{array}$ \\
\hline 11. Export of Goods and Services (in \% of GDP) & $\begin{array}{l}\text { 11. Private Credit by Deposit Money } \\
\text { Banks and Other Financial Institutions to } \\
\text { GDP }(\%)\end{array}$ \\
\hline 12. Import of Goods and Services (in \% of GDP) & 12. Stock price volatility \\
\hline 13. Export+ Import in \% of GDP & 13. Stock Market Turnover Ratio (\%) \\
\hline $\begin{array}{l}\text { 14. Export (all products) of Germany from } \\
\text { different PIIGS nations in \% of GDP }\end{array}$ & $\begin{array}{l}\text { 14. Stock Market Capitalization to GDP } \\
(\%)\end{array}$ \\
\hline $\begin{array}{l}\text { 15. Import (all products) of Germany by different } \\
\text { PIIGS nations in } \% \text { of GDP }\end{array}$ & $\begin{array}{l}\text { 15. Gross Portfolio Debt Assets to GDP } \\
(\%)\end{array}$ \\
\hline $\begin{array}{l}\text { 16. \%Change over previous year in National } \\
\text { Currency to US Dollar Spot Exchange Rate, US } \\
\text { Dollar per National Currency Units, Annual, Not } \\
\text { Seasonally Adjusted }\end{array}$ & $\begin{array}{l}\text { 16. Gross Portfolio Debt Liabilities to } \\
\text { GDP }(\%)\end{array}$ \\
\hline 17. REER $(2010=100)$ & $\begin{array}{l}\text { 17. Gross Portfolio Equity Assets to GDP } \\
(\%)\end{array}$ \\
\hline $\begin{array}{l}\text { 18. External Balance on Goods And Services (\% } \\
\text { of GDP) }\end{array}$ & $\begin{array}{l}\text { 18. Gross Portfolio Equity Liabilities to } \\
\text { GDP }(\%)\end{array}$ \\
\hline 19. Net Income from Abroad (in \% of GDP) & $\begin{array}{l}\text { 19. Portfolio Equity, Net Inflows (BoP, in } \\
\text { \% OF GDP) }\end{array}$ \\
\hline 20. Budget Balance (\% of GDP) & $\begin{array}{l}\text { 20. Stock Market Total Value Traded to } \\
\text { GDP }(\%)\end{array}$ \\
\hline 21. Gross Saving \% of GDP & $\begin{array}{l}\text { 21. Stocks Traded, Total Value (\% of } \\
\text { GDP) }\end{array}$ \\
\hline 22. Gross Domestic Saving \% of GDP & $\begin{array}{l}\text { 22. Stock Market Return (\%, year-on- } \\
\text { year) }\end{array}$ \\
\hline 23. Remittance Inflows to GDP (\%) & $\begin{array}{l}\text { 23. Total Share Prices for All Shares Index } \\
2010=1 \text {, Annual, Not Seasonally Adjusted }\end{array}$ \\
\hline
\end{tabular}




\begin{tabular}{|c|c|}
\hline $\begin{array}{l}\text { 24. General Government Financial Wealth Total, } \\
\% \text { of GDP }\end{array}$ & $\begin{array}{l}\text { 24. Net Lending }(+) / \text { Net Borrowing }(-) \\
(\% \text { of GDP) }\end{array}$ \\
\hline 25. Total Reserves (includes gold, in \% of GDP) & $\begin{array}{l}\text { 25. Immediate Rates: Less than } 24 \text { Hours: } \\
\text { Call Money/Interbank Rate in \% }\end{array}$ \\
\hline 26. Total Reserves (minus gold, in \% of GDP) & $\begin{array}{l}\text { 26. Long-term Interest Rates Total, \% per } \\
\text { annum }\end{array}$ \\
\hline 27. Tax Revenue (\% of GDP) & $\begin{array}{l}\text { 27. Short term Interest Rate (\%per } \\
\text { annum) }\end{array}$ \\
\hline $\begin{array}{l}\text { 28. General Government Revenue, Total, \% of } \\
\text { GDP }\end{array}$ & $\begin{array}{l}\text { 28. Outstanding Domestic Public Debt } \\
\text { Securities to GDP (\%) }\end{array}$ \\
\hline $\begin{array}{l}\text { 29. General Government Spending by } \\
\text { Destination Individual, \% of GDP }\end{array}$ & $\begin{array}{l}\text { 29. Outstanding International Public Debt } \\
\text { Securities to GDP\% Annual, Not } \\
\text { Seasonally Adjusted }\end{array}$ \\
\hline $\begin{array}{l}\text { 30. General Government Spending by } \\
\text { Destination Society, \% of GDP }\end{array}$ & $\begin{array}{l}\text { 30. Outstanding Domestic Private Debt } \\
\text { Securities to GDP (\%) }\end{array}$ \\
\hline 31. General Government Spending (in \% of GDP) & $\begin{array}{l}\text { 31. Outstanding International Private } \\
\text { Debt Securities to GDP, Percent, Annual, } \\
\text { Not Seasonally Adjusted }\end{array}$ \\
\hline $\begin{array}{l}\text { 32. Public Spending on Education, Total (\% of } \\
\text { GDP) }\end{array}$ & $\begin{array}{l}\text { 32. General Government Debt Total, \% of } \\
\text { GDP }\end{array}$ \\
\hline 33. Health Expenditure, Public (\% of GDP) & Banking Variables \\
\hline 34. Military Expenditure (\% of GDP) & $\begin{array}{l}\text { 1. Bank Nonperforming Loans to Total } \\
\text { Gross Loans (\%) }\end{array}$ \\
\hline $\begin{array}{l}\text { 35. Research and Development Expenditure ( } \% \\
\text { of GDP) }\end{array}$ & 2. Bank Capital to Assets Ratio (\%) \\
\hline 36. Pension Fund Assets to GDP (\%) & 3. Central Bank Assets to GDP (\%) \\
\hline $\begin{array}{l}\text { 37. Final Consumption Expenditure, etc. ( } \% \text { of } \\
\text { GDP) }\end{array}$ & $\begin{array}{l}\text { 4. Domestic Credit to Private Sector by } \\
\text { Banks ( } \% \text { of GDP) }\end{array}$ \\
\hline $\begin{array}{l}\text { 38. Production of Total Construction, Index } \\
2010=100 \text {, Annual, Not Seasonally Adjusted }\end{array}$ & $\begin{array}{l}\text { 5. Loans from Nonresident Banks (net) to } \\
\text { GDP }(\%)\end{array}$ \\
\hline 39. Total Central Govt. Debt $\%$ of GDP & $\begin{array}{l}\text { 6. Deposit Money Banks' Assets to GDP } \\
(\%)\end{array}$ \\
\hline $\begin{array}{l}\text { 40. Production of Total Industry Index 2010=100, } \\
\text { Annual, Not Seasonally Adjusted }\end{array}$ & $\begin{array}{l}\text { 7. Bank Credit to Bank Deposits Percent, } \\
\text { Annual, Not Seasonally Adjusted }\end{array}$ \\
\hline 41. GDP per Hour Worked $(2010=100)$ & $\begin{array}{l}\text { 8. Bank's Cost to Income Ratio, Percent, } \\
\text { Annual, Not Seasonally Adjusted }\end{array}$ \\
\hline $\begin{array}{l}\text { 42. Labour Productivity per Hour Worked, } \\
\text { Annual Growth Rate (\%) }\end{array}$ & $\begin{array}{l}\text { 9. Bank Regulatory Capital to Risk- } \\
\text { Weighted Assets Percent, Annual, Not } \\
\text { Seasonally Adjusted }\end{array}$ \\
\hline $\begin{array}{l}\text { 43. Labour Productivity, Annual Growth Rate } \\
(\%)\end{array}$ & $\begin{array}{l}\text { 10. 3-Month or 90-day Rates and Yields: } \\
\text { Interbank Rates Percent, Annual, Not } \\
\text { Seasonally Adjusted }\end{array}$ \\
\hline
\end{tabular}




\begin{tabular}{|c|c|}
\hline 44. Manufacturing, Value Added (\% of GDP) & Social Variables \\
\hline 45. Industry, Value Added (\% of GDP) & $\begin{array}{l}\text { 1. Political Stability and Absence of } \\
\text { Violence/ Terrorism }\end{array}$ \\
\hline 46. Agriculture, Value Added (\% of GDP) & 2. Rule of Law \\
\hline $\begin{array}{l}\text { 47. Total Production of Investment Goods for } \\
\text { Manufacturing, Index } 2010=1 \text {, Annual, Not } \\
\text { Seasonally Adjusted }\end{array}$ & 3. Governance Effectiveness \\
\hline 48. Labour Utilisation Annual Growth Rate & 4. Regulator Quality \\
\hline $\begin{array}{l}\text { 49. Unit Labour Costs by Persons Employed, } \\
\text { Percentage Change, Previous Period }\end{array}$ & 5. Control of Corruption \\
\hline $\begin{array}{l}\text { 50. Unit Labour Costs by Hours Worked, } \\
\text { Percentage Change, Previous Period }\end{array}$ & $\begin{array}{l}\text { 6. Unemployment, Total (\% of total labor } \\
\text { force) (modeled ILO estimate) }\end{array}$ \\
\hline 51. Gross Fixed Capital Formation ( $\%$ of GDP) & 7. Birth Rate, Crude (per 1,000 people) \\
\hline $\begin{array}{l}\text { 52. Gross fixed capital formation (annual \% } \\
\text { growth) }\end{array}$ & 8. Death Rate, Crude (per 1,000 people) \\
\hline 53. Gross Capital Formation ( $\%$ annual growth) & $\begin{array}{l}\text { 9. Age Dependency Ratio (\% of working- } \\
\text { age population) }\end{array}$ \\
\hline 54. Gross Capital Formation (\% of GDP) & 10. Age Dependency Ratio, Old \\
\hline 55. FDI Net Outflow (in \% of GDP) & 11. Age Dependency Ratio, Young \\
\hline 56. FDI Net Inflow (in \% of GDP) & $\begin{array}{l}\text { 12. Labor Force with Advanced } \\
\text { Education (\% of total) }\end{array}$ \\
\hline \multirow[t]{2}{*}{ 57. Net FDI in $\%$ of GDP } & $\begin{array}{l}\text { 13. Labor Force with Basic Education (\% } \\
\text { of total) }\end{array}$ \\
\hline & $\begin{array}{l}\text { 14. Rural Population (\% of total } \\
\text { population) }\end{array}$ \\
\hline
\end{tabular}

Source: Based on Author's Calculation

\section{Normalization of Data:}

In order to know weather data is normalized or not, the paper has conducted Jarque-Bera test on each of the variables for every PIIGS country. The data set is identified into normal and non-normal data set through Jarque-Bera test. In Jarque- Bera test:

$\mathbf{H} \mathbf{0}=$ The data belongs to normal distribution

H1= The data does not belong to normal distribution
Maximum tests for normality are grounded either on linking the observed accumulative distribution with the theoretical normal accumulative distribution (as in case of normality tests like Kolmogorov-Smirnov, Anderson-Darling, Chi-Square test) or realistic quantiles with the hypothetical normal quantiles for example in normality tests like Probability Plot Correlation Coefficient Test (PPCC), Wilk-Shapiro. In opposite to this, the Jarque-Bera test is based on the sample kurtosis and sample skewness. 
The Jarque-Bera test statistic is defined as:

$$
J B \text { Test Static }=\frac{N}{6}\left[S^{2}+\frac{(K-3)^{2}}{4}\right]
$$

Where, $\mathrm{S}=$ Sample Skewness

$\mathrm{K}=$ Sample Kurtosis

and, $\mathrm{N}=$ Sample Size
The result of Jarque-Bera test is done on the basis of probability values. If probability is less than $5 \%$ than it goes in favour of alternate hypothesis and viceversa. In case of each country some variables found to be non-normal. The different variables were transformed in the process of make them normal by taking their log value, first difference, second difference, reciprocal and other transformations. The transformed data is tabulated in Table 2.

Table 2 : Data Transformed into Normal Data

Variables Transformed to Normal Variables of Different BRIC Countries

I. Portugal

1. Log Long-term Interest Rates Total (\% per annum)

2. Log Stock Market Turnover Ratio (\%)

3. Log Stocks Traded, Total Value (\% of GDP)

4. Log Total Reserves Minus Gold (in \% of GDP)

II. Ireland

1. 1st Difference of FDI Net Inflow (\% OF GDP)

2. Log Gross Domestic Savings (\% of GDP)

3. Log Total Reserves (includes gold, in \% of GDP)

4. Log Bank Capital to Assets Ratio (\%)

5. Log Central Bank Assets to GDP (\%)

6. Log GDP in Constant LCU

7. 1st Difference of FDI Net Outflow (in \% of GDP)

8. 1st Difference of Budget Balance (in \% of GDP)

9. Log Stock Price Volatility, Index, Annual, Not Seasonally Adjusted

10. Log Stocks Traded, Total Value (\% of GDP)

11. Log Stock Market Total Value Traded to GDP (\%)

12. Log Stock Market Turnover Ratio (\%)

13. Log General Government Spending (in \% of GDP)

14. Log GDP per Hour Worked $(2010=100)$

15. 1st Difference of Export (all products) of Germany from Different PIIGS Countries in \% of GDP

16. Reciprocal of 1st Difference of Final consumption Expenditure, etc. (\% of GDP)

17. Log Total Reserves minus Gold (in \% of GDP)

18. Reciprocal of 2nd Difference of Net Income from Abroad (in \% of GDP)

19. 1st Difference of Net lending (+) / Net Borrowing (-) (\% of GDP)

20. 1st Difference of Labour Productivity, Annual Growth Rate (\%)

21. Reciprocal of 2nd Difference of General Government Revenue Total, \% of GDP

22. 2nd Difference of Production of Total Industry, Index 2010=100, Annual, Not Seasonally Adjusted 


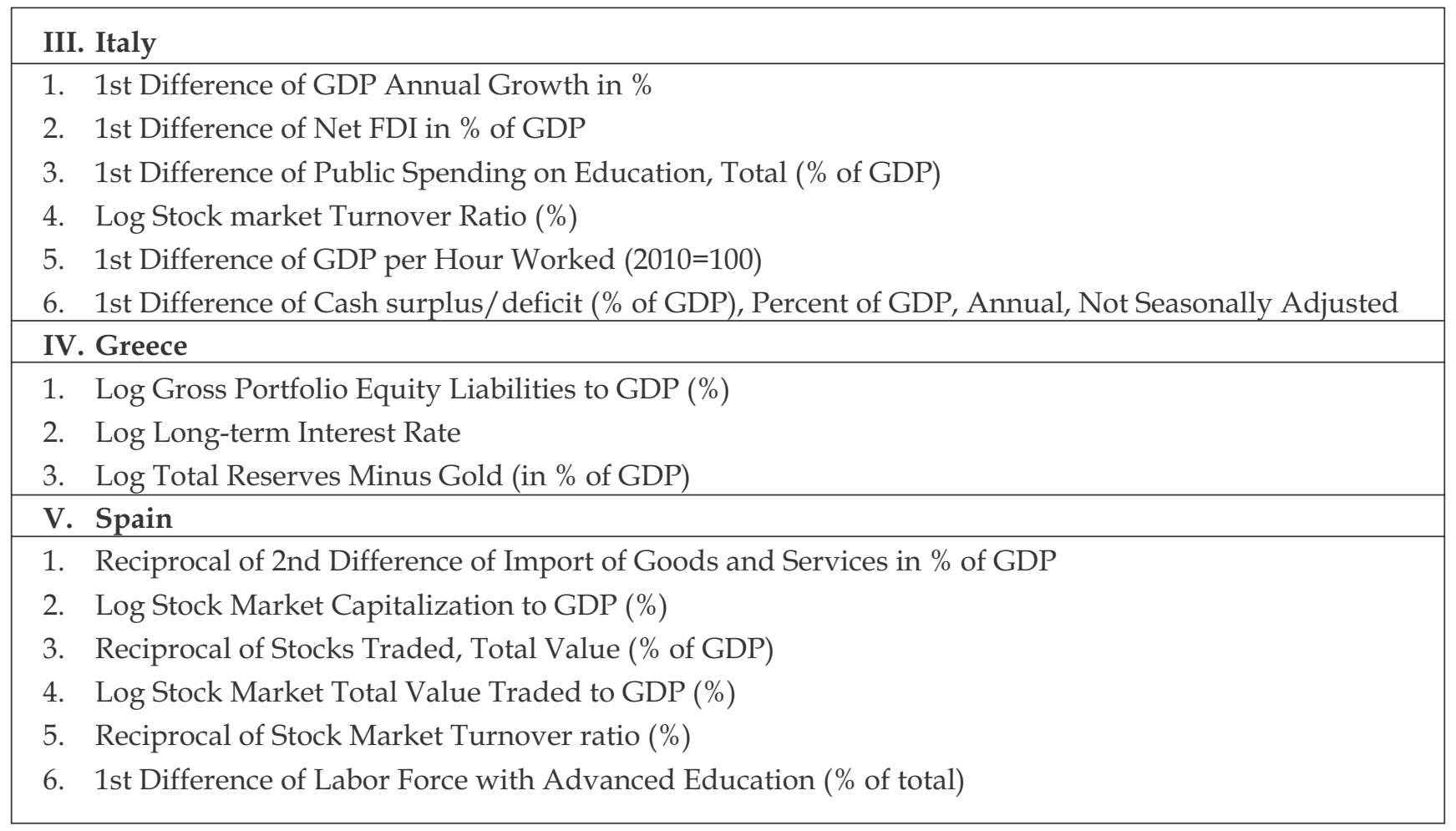

Source: Based on Author's Calculation

\section{Methodology}

In a time series data structural break occurs when there is sudden change in the trend line is seen. The time series data starts to follow new trend line after the sudden change with different slope and/or intercept.

To get the triggering point of the crisis this part of analysis uses signaling mechanism in the structural breaks analysis. In this attempt annual data for various variables (identified from literature review) were used. The whole period after formation of the Euro-zone was divided in to three categories: precrisis period, crisis period and post crisis period. Here is the step-by-step procedure used to identify the structural breaks:

1. Affected variables are identified with the help of literature review. The data was collected in annual form for the duration 2001 to 2015.
2. To chalk out structural breaks in variables in the above mentioned three periods; i.e. pre-crisis period, crisis period and post crisis period. Two dummy variables $\mathrm{d} 1$ and $\mathrm{d} 2$ were used for this purpose.

3. To analyses problematic PIIGS nations with the respect to selected variables. These five nations were selected because of their vulnerable nature at the time of the crisis.

\subsection{Crisis Window}

The period of crisis emergence is taken as 2008-09. As per Sebastian Dullien (2010) in "Risk Variables in International Financial Crises: Early Lessons from the 2008-2009 Turmoil" both 2008 and 2009 years have been taken as years of Euro zone crisis ${ }^{1}$. The introduction part of this paper also supports that the crisis started in 2008 and showed its severe impact in 2009 as well. So, both the years are taken as crisis window. Yearly data are taken for various variables

1. As per "Risk Factors in International Financial Crises: Early Lessons from the 2008-2009 Turmoil "by Sebastian Dullien in "The Financial and Economic Crisis" of 2008-2009 and Developing Countries. 
to study the crisis. The important assumption of this paper is that crisis is taken here as a medium term phenomenon so short term monthly data is not taken for the study. The theory of co-integration is also not used here; as the same used to study the long-term phenomenon.

\subsection{Testing for Structural Break}

Three periods are taken for the study; so to know the effect of crisis on the trend of the variables; two dummies ( $\mathrm{d} 1$ and $\mathrm{d} 2$ ) are used. If any changes in the trend of the variables are present; the analysis checked it through its significance level. The precrisis period is taken as a benchmark period and all the comparisons of change in trend is done by comparing it with the benchmark period. The structural break analysis is done with the assistance of following equation:

$V A R i j=a+b 1 D 1+b 2 D 2+b 3 t+b 4 D 1 t+b 5 D 2 t+e ;$ where, $V A R i j=$ Variables

$\mathrm{a}=$ intercept

D1, D2= crisis period and post crisis period intercept dummy respectively.

$\mathrm{D} 1 \mathrm{t}=$ tendency in the crisis period (slope dummy)

$\mathrm{D} 2 \mathrm{t}=$ tendency in the post crisis period (slope dummy)

b1=change in intercept among pre-crisis and crisis period

$\mathrm{b} 2=$ change in intercept in pre-crisis and post-crisis period

b3= slope of the period

$\mathrm{b} 4=$ difference in the slope among pre-crisis and crisis period

$\mathrm{b} 5=$ difference in the slope among pre-crisis and post-crisis period

$\mathrm{e}=$ error term for ' $\mathrm{i}$ ' country and ' $\mathrm{j}$ ' variable

D1 $=0\{$ (for 2001-2007) and(for 2010-2015) $;$; =1 (for

2008-20009)

D2= 0 (for 2001-2009) and $=1$ (for 2010-2015)

The variable, which shows structural breaks in their trend, is helpful in explaining the crisis. The structural break is detected with the help of significant changes in the intercept and/or slope of the trend. The coefficients b1 and b2 would represent structural breaks (if any) in the value of the variables used in the study; in the crisis and post crisis period as compared to the pre-crisis period. Similarly, b4 and b5 represent structural breaks (if present) in the trend of the variables in crisis and post crisis period respectively as compared to the pre-crisis period.

\section{RESULTS AND ANALYSIS}

After applying the Jarque-Bera test for checking normality. The test found some of the variables are non-normal in case of each country. The variables which were not found normal were transformed in the process of make them normal by taking their log value, first difference, second difference, reciprocal and other transformations. The final data set of normal variables is given in Table 2 .

All these 113 different Variables were analysed in this paper under structural break analysis.

\section{Studying Structural Breaks}

1. Generally structural breaks studies are used to get long run change in the variable; for example change in technology or management. To study this medium term effect of the Euro-crisis with the assistance of the structural breaks is somewhat difficult. At the other hand if the variables were touched significantly and sufficiently it would surely show the effect of the crisis with the help of this structural break analysis, even in for the medium term.

2. The dummy variables also valuable in detecting stages of recovery process in terms of particular variable. Following four cases are possible:

i) If both of the D2 and D2t coefficients are statistically insignificant then it indicate that the recovery process is complete.

ii) If signs of both of the D2 and D2t coefficients are same as the pre-crisis period and they are statistically significant it means that the recovery is not complete i.e. it is partial. 
iii) If the signs of both the D2 and D2 are different as compared to the pre-crisis period and both the coefficients are statistically significant then it shows that the recovery process is not started as yet and the crisis has shaken the variable badly.

iv) If both of coefficients of D1 and D2 are having with the same sign it reveals that there is no recovery in that variable and vice versa.

Dummy variable exercise can be interpreted as follows:

i) Significant coefficients of D1t and D2t represent structural break in the trend where as significant coefficients of D1 and D2 show structural break in the intercept of the variable.

ii) Positive value of coefficients of D1 and D1t show increase in the intercept and slope of the variable in the crisis period as compared to the pre-crisis period.

iii) Negative value of coefficients of D1 and D1t show lessening of the intercept and slope of the variable in the crisis period as compared to the pre-crisis period.

iv) Positive value of coefficients of D2 and D2t show escalation in the intercept and slope of the variable in the post-crisis period as compared to the pre-crisis period.

v) Negative value of coefficients of D2 and D2t show decrease in the intercept and slope of the variable in the post-crisis period as compared to the pre-crisis period.

vi) The slope dummy i.e. D1t and D2t have their influence on the particular variable over a phase of time. At the other hand, the intercept dummy i.e. D1 and D2 has their effect on the variable at a point of time only.

The result is summarized for each of the PIIGS nations. Variables that have D1, D2, D1t and D2t significant are quoted in the result section. The result is checked at $1 \%, 5 \%$ and $10 \%$ level of significance.

\section{Country-wise Analysis}

This paper successfully able to find out the significant variables in crisis period among different variables for PIIGS nation and named them as crisis affected variables for that nation. Also, it analyses different trends followed by different crisis variables in different PIIGS nations in crisis period (2008-09) and post crisis period (2010-15). In this way this paper confirms the broad hypothesis that all of the PIIGS nations has been seriously affected by the crisis. The following tables shows there are some common economic variables those put all of the PIIGS nations in one shell of European peripheral countries. The Table 3 gives the collective variables, affected by the severity of the crisis in each of the PIIGS nations:

Structural break is found in all above variables given in table in case of every PIIGS nations. These structural breaks are also easily visible in the crisis period 2008-2009 in many of the variables. Few of the variables are graphed below over the period of

Table 3 : Common Variables Being Affected by the Crisis in Each of the PIIGS Nations
1. CPI Inflation
2. Current Account Balance
3. GDP in Current US\$
4. Total Reserves (includes gold, in \% of GDP)
5. Total Reserves (minus gold, in \% of GDP)
6. External Balance on Goods and Services (\% of GDP)
7. Agriculture, Value Added (\% of GDP)
8. Manufacturing, Value Added ( $\%$ of GDP) 
9. Net Investment in Nonfinancial Assets (\% of GDP)

10. General Government Financial Wealth Total, \% of GDP

11. $\operatorname{REER}(2010=100)$

12. Export of Goods and Services (in \% of GDP)

13. Export+Import in \% of GDP

14. Export (all products) of Germany from different PIIGS Countries in \% of GDP

15. Total Production of Investment Goods for Manufacturing for PIIGS, Index 2010=1, Annual, Not Seasonally Adjusted

16. Gross Saving \% of GDP

17. Gross Domestic Saving \% of GDP

18. Rule of Law

19. General Government Spending by Destination Individual, $\%$ of GDP

20. General Government Spending by Destination Society, \% of GDP

21. Health Expenditure, Public (\% of GDP)

22. Age Dependency Ratio (\% of working-age population)

23. Age Dependency Ratio, Old

24. Age Dependency Ratio, Young

25. Birth Rate, Crude (per 1,000 people)

26. Rural Population (\% of total population)

27. Domestic Credit to Private Sector by Banks (\% of GDP)

28. Short term Interest Rate (\%per annum)

29. PIIGS-3-Month or 90-day Rates and Yields: Interbank Rates Percent, Annual, Not Seasonally Adjusted

30. Immediate Rates: Less than 24 Hours: Call Money/Interbank Rate in \%

Source: Author'sown Calculation

analysis 2001 to 2015. In theses graph the breaking pattern is easily visible during the crisis period.
In the entire above graphs the structural break can be easily seen during the crisis period. A sudden change in the trend of the variables is visible in crisis

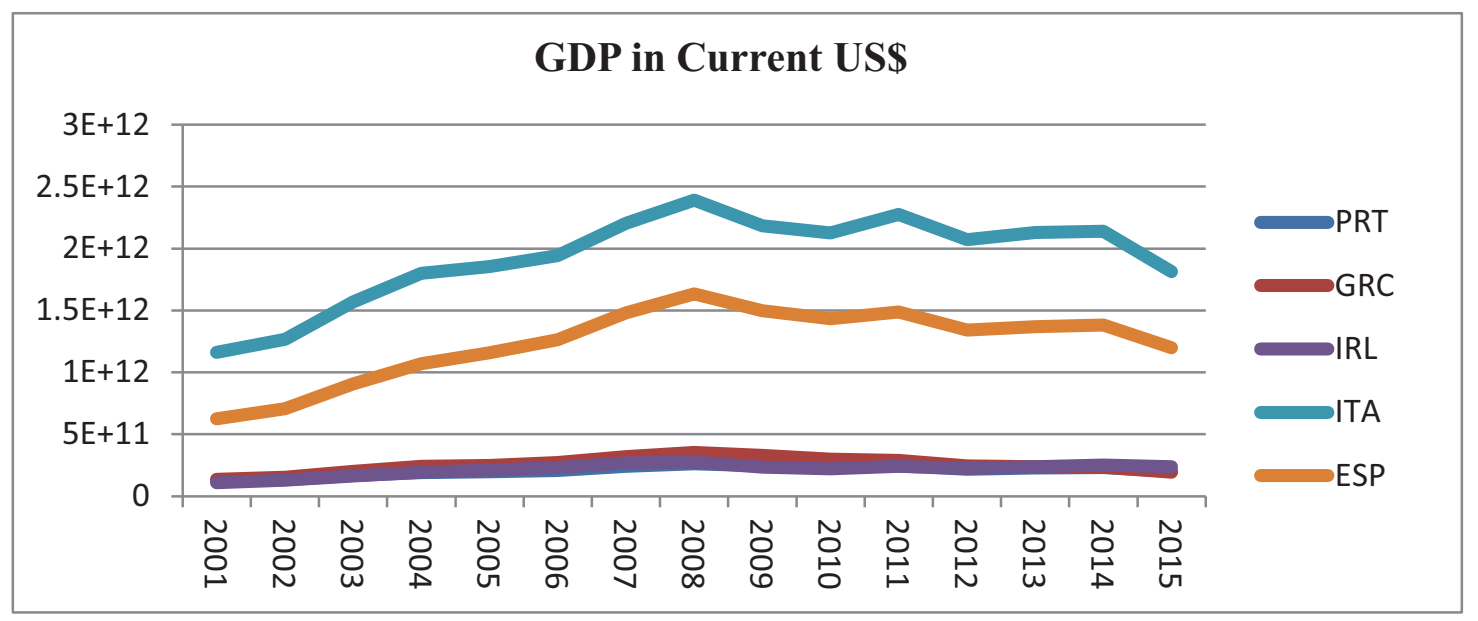

Source: World Bank

Graph - 1 : Structural Break in Different Variables (Current US\$, CPI Inflation and Current Account Balance) in PIIGS Nations 


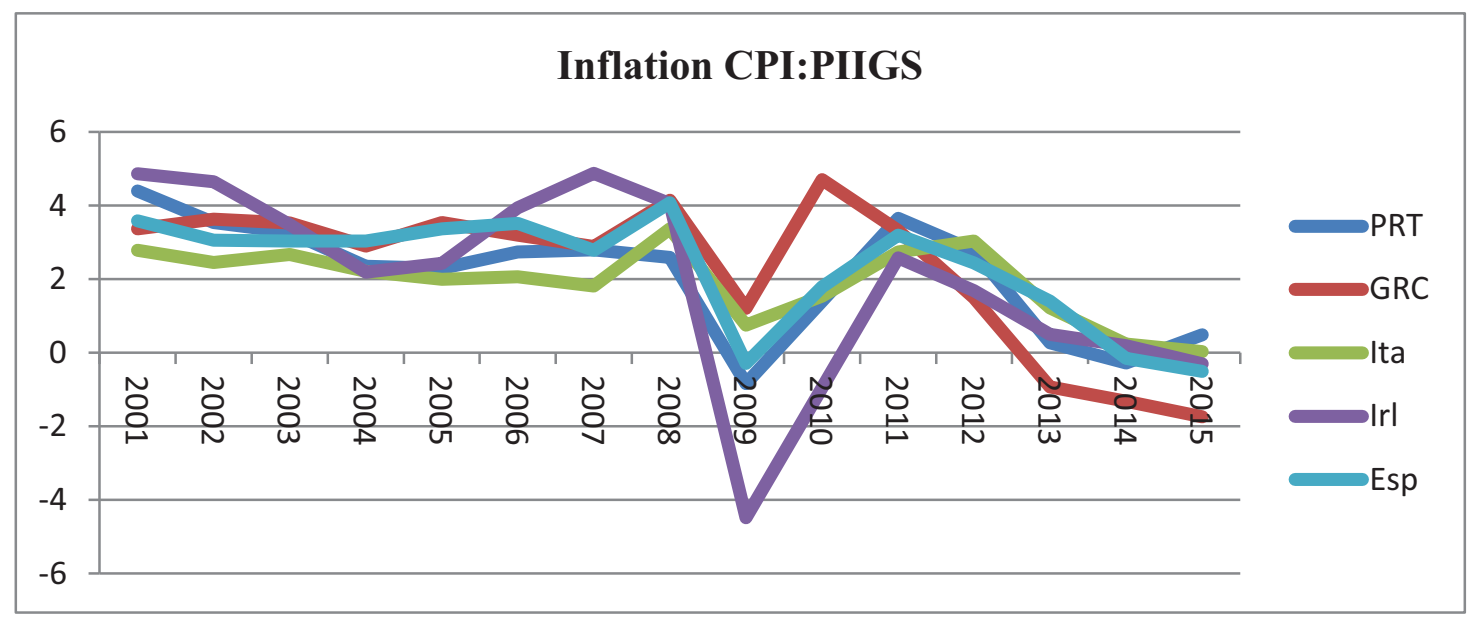

Source: World Bank

\section{Graph - 2}

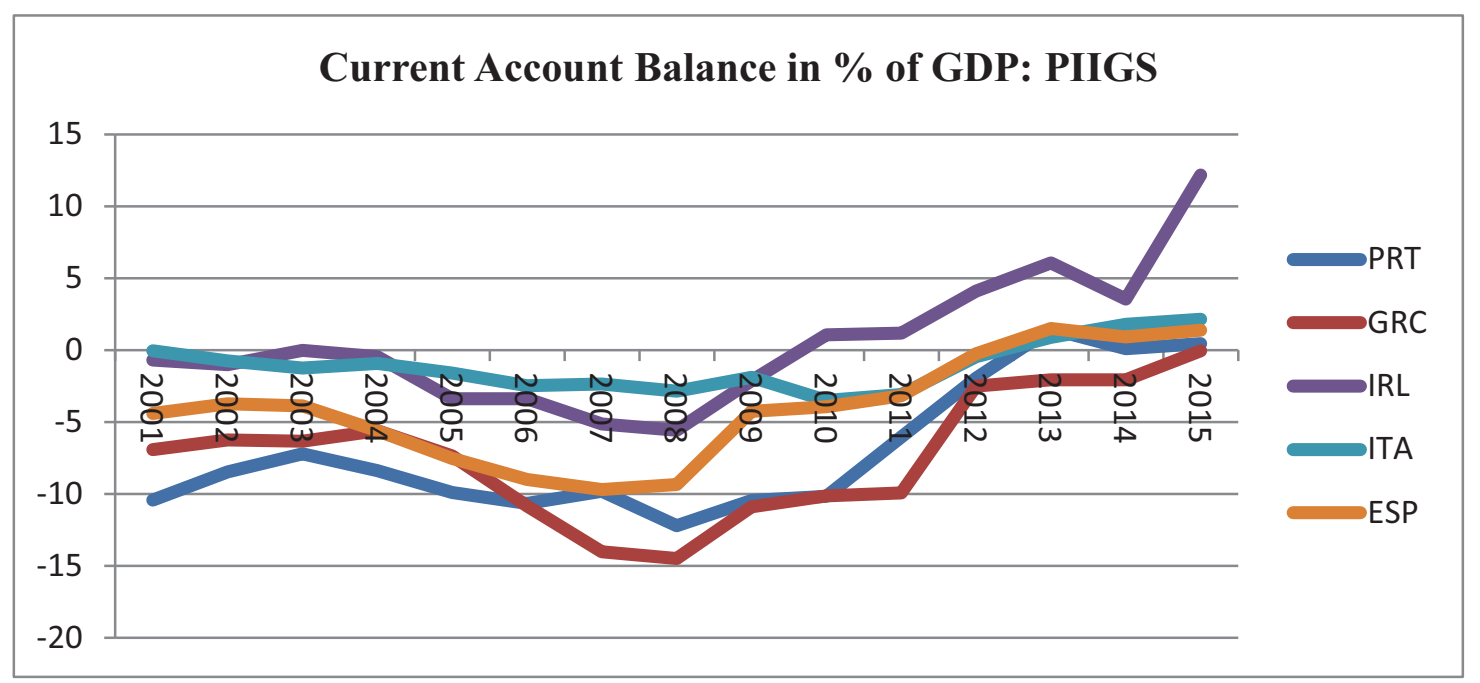

Source: World Bank

\section{Graph - 3}

period. In case of CPI Inflation, GDP in Current US\$ and Current Account Balance in percentage of GDP the sudden plunge can be seen during 2008-09; with clarity. These breaks were tested in the present paper in each of the variable for every PIIGS nation with the help of dummy variable exercise.

All the PIIGS nations were severely hit by the crisis but in different ways; i.e. in one country if a variable is affected then there are examples that at the same time in another country the particular variable is not affected significantly.
Table 4 shows Spain is the most affected country among PIIGS nations both during the crisis and after the crisis. It also indicates that the recovery is relatively slow in Spain. The Table 4 also shows that the crisis recovery in Italy is rather fast. When it comes to during crisis Portugal is least affected. In post crisis period Portugal is not least affected. The least affected country in the post crisis period is either Ireland or Italy. When it comes to total period both during and post crisis period Ireland comes out to be least affected with 67 significant variables among 113 total variables. 
Table 4 : Most and Least Affected PIIGS Country at Different Level of Significance

\begin{tabular}{|l|l|l|l|l|l|l|l|}
\hline & $\begin{array}{l}\text { In Totality at } \\
10 \% \text { Level of } \\
\text { Significance }\end{array}$ & \multicolumn{2}{|l|}{$\begin{array}{l}\text { At 1\% Level of } \\
\text { Significance }\end{array}$} & \multicolumn{2}{l|}{$\begin{array}{l}\text { At 5\% Level of } \\
\text { Significance }\end{array}$} & \multicolumn{2}{l|}{$\begin{array}{l}\text { At 10\% Level of } \\
\text { Significance }\end{array}$} \\
\hline & $\begin{array}{l}\text { During } \\
\text { Crisis }\end{array}$ & $\begin{array}{l}\text { After } \\
\text { Crisis }\end{array}$ & $\begin{array}{l}\text { During } \\
\text { Crisis }\end{array}$ & $\begin{array}{l}\text { After } \\
\text { Crisis }\end{array}$ & $\begin{array}{l}\text { During } \\
\text { Crisis }\end{array}$ & $\begin{array}{l}\text { After } \\
\text { Crisis }\end{array}$ \\
\hline $\begin{array}{l}\text { Most } \\
\text { Affected } \\
\text { Country }\end{array}$ & Spain & Spain & Spain & Spain & Spain & Spain & Spain \\
\hline $\begin{array}{l}\text { Least } \\
\text { Affected } \\
\text { country }\end{array}$ & Ireland & Portugal & $\begin{array}{l}\text { Ireland } \\
\text { and } \\
\text { Portugal }\end{array}$ & Portugal & Italy & Portugal & Italy \\
\hline
\end{tabular}

Source: Based on Author's Calculation

After analyzing 113 different Variables 106Variables found to be significant variables at $10 \%$ level of significance, which were affected by the crisis in different PIIGS nations (the same is reported in Table 5). The structural breaks were found in trend-line of these 106 Variables during crisis period (2008-09) and post crisis period (2010-2015). The most affected country among PIIGS nations is Spain with 87 significant variables and the least affected country is Ireland with 67 significant variables.

In case of Portugal 71variables found to be significant during crisis period. In case of Ireland the 67variables found to be affected by the crisis. In case of Italy 69 different economic variables are impacted by the crisis. In case of Greece total 70 variables are found to be impacted by the crisis. In case of Spain 87 variables were significantly impacted on the emergence of the crisis. The details of performance of above significant Variables during crisis and after crisis period are summarized in Table 4.

In Ireland some of its economic fundamental variables sustained its GDP growth in post crisis period; such as export growth, high productivity, relatively flexible labour market improvements in competitiveness and unit labour cost. Ireland improved its unit labour cost most effectively and significantly as compared to any other crisis facing Eurozone country. These fundamental variables helped Ireland to adjust for fiscal contraction more easily as compared to other EMU nations. From August 2011 the investors' attitudes towards Irish sovereign bond has been started refining. From mid of 2013 the Irish government issued its long-term sovereign bonds well in numbers with the rates reached to the pre crisis level (Karl Whelan, 2014).

As per the news in The Guardian on 13 December 2013, Ireland exited from the EU-IMF-ECB financed bailout and became the very first among crisis countries leaving the bailout programme.

In Ireland the economic growth commenced in 2012 and this growth sustained in 2013 and 2014 after the episode of crisis. The approach of Ireland in dealing with the crisis is different from the approach of Spain in recovering its economy. In case of Spain there is over promising and under delivering approach just opposite to the Ireland's under promising and over delivering approach. In spring of 2010 Spain has over planned adjustment in its public finances as compared to Ireland. Due to political reasons Spain was fail to meet the planned adjustment in public finances and by this way it has lost reliability in the financial market for short run. This resulted in the rise in bond yields in Spain as compared to Ireland (John Fitzgerald, 2014). 
Table 5 : Statistically Significant Variables, which shows Structural Breaks in Case of PIIGS Nations (segregated in Macro/Financial/Banking and Social Variables):

\begin{tabular}{|l|l|l|l|l|l|}
\hline & PRT & IRL & ITA & GRC & ESP \\
\hline A. Macro Economic Variables & & & & & \\
\hline 1. GDP (in current US\$) & $\checkmark$ & $\checkmark$ & $\checkmark$ & $\checkmark$ & $\checkmark$ \\
\hline 2. GDP (in constant LCU) & $\checkmark$ & & $\checkmark$ & $\checkmark$ & $\checkmark$ \\
\hline 3. GDP (in current LCU) & $\checkmark$ & & $\checkmark$ & $\checkmark$ & $\checkmark$ \\
\hline 4. CPI Inflation & $\checkmark$ & $\checkmark$ & $\checkmark$ & $\checkmark$ & $\checkmark$ \\
\hline 5. GDP per Capita (in \% of GDP) & $\checkmark$ & $\checkmark$ & & $\checkmark$ & $\checkmark$ \\
\hline 6. GDP Annual Growth (in \%) & & $\checkmark$ & & $\checkmark$ & $\checkmark$ \\
\hline 7. Inflation in GDP Deflator & $\checkmark$ & $\checkmark$ & & & $\checkmark$ \\
\hline $\begin{array}{l}\text { 8. Cash Surplus } \text { Deficit (\% of GDP) Percent of } \\
\text { GDP, Annual, Not Seasonally Adjusted }\end{array}$ & $\checkmark$ & & $\checkmark$ & $\checkmark$ & $\checkmark$ \\
\hline 9. CA Balance (in \% of GDP) & $\checkmark$ & $\checkmark$ & $\checkmark$ & $\checkmark$ & $\checkmark$ \\
\hline \begin{tabular}{l} 
10. Export of Goods and Services (in \% of GDP) \\
\hline 11. Import of Goods and Services (in \% of GDP)
\end{tabular} & $\checkmark$ & $\checkmark$ & $\checkmark$ & $\checkmark$ & $\checkmark$ \\
\hline 12. Export Import in \% of GDP & $\checkmark$ & $\checkmark$ & $\checkmark$ & $\checkmark$ & \\
\hline $\begin{array}{l}\text { 13. Export (all products) of Germany from } \\
\text { different PIIGS nations in \% of GDP }\end{array}$ & $\checkmark$ & $\checkmark$ & $\checkmark$ & $\checkmark$ & $\checkmark$ \\
\hline $\begin{array}{l}\text { 14. Import (all products) of Germany by different } \\
\text { PIIGS nations in \% of GDP }\end{array}$ & $\checkmark$ & & & $\checkmark$ & $\checkmark$ \\
\hline 15. REER (2010=100) & $\checkmark$ & $\checkmark$ & $\checkmark$ & $\checkmark$ & $\checkmark$ \\
\hline $\begin{array}{l}\text { 16. External Balance on Goods and Services (\% of } \\
\text { GDP) }\end{array}$ & $\checkmark$ & $\checkmark$ & $\checkmark$ & $\checkmark$ & $\checkmark$ \\
\hline 17. Net Income from Abroad (in \%of GDP) & $\checkmark$ & & $\checkmark$ & $\checkmark$ & $\checkmark$ \\
\hline 18. Budget Balance (\% of GDP) & $\checkmark$ & & $\checkmark$ & & $\checkmark$ \\
\hline 19. Gross Saving \% of GDP & $\checkmark$ & $\checkmark$ & $\checkmark$ & $\checkmark$ & $\checkmark$ \\
\hline 20. Gross Domestic Saving \% of GDP & $\checkmark$ & $\checkmark$ & $\checkmark$ & $\checkmark$ & $\checkmark$ \\
\hline 21. Remittance Inflows to GDP (\%) & $\checkmark$ & & $\checkmark$ & & $\checkmark$ \\
\hline $\begin{array}{l}\text { 22. General Government Financial Wealth Total, \% } \\
\text { of GDP }\end{array}$ & $\checkmark$ & $\checkmark$ & $\checkmark$ & $\checkmark$ & $\checkmark$ \\
\hline 23. Total Reserves (includes gold, in \%of GDP) & $\checkmark$ & $\checkmark$ & $\checkmark$ & $\checkmark$ & $\checkmark$ \\
\hline 24. Total reserves (minus gold, in \%of GDP) & $\checkmark$ & $\checkmark$ & $\checkmark$ & $\checkmark$ & $\checkmark$ \\
\hline 25. Tax Revenue (\% of GDP) & $\checkmark$ & $\checkmark$ & & $\checkmark$ & \\
\hline 26. General Government Revenue Total, \% of GDP & $\checkmark$ & & & $\checkmark$ & $\checkmark$ \\
\hline 27. General Government Spending (in \% of GDP) & $\checkmark$ & $\checkmark$ & $\checkmark$ & & $\checkmark$ \\
\hline $\begin{array}{l}\text { 28. General Government Spending by Destination, } \\
\text { Individual, \% of GDP }\end{array}$ & $\checkmark$ & $\checkmark$ & $\checkmark$ & $\checkmark$ & $\checkmark$ \\
\hline $\begin{array}{l}\text { 29. General Government Spending by Destination } \\
\text { Society, \% of GDP }\end{array}$ & $\checkmark$ & $\checkmark$ & $\checkmark$ & $\checkmark$ & $\checkmark$ \\
\hline $\begin{array}{l}\text { 30. Public Spending on Education, Total (\% of } \\
\text { GDP) }\end{array}$ & & $\checkmark$ & & & \\
\hline 31. Health Expenditure, Public (\% of GDP) & $\checkmark$ & $\checkmark$ & $\checkmark$ & $\checkmark$ & $\checkmark$ \\
\hline $\begin{array}{l}\text { 32. Research and Development Expenditure (\% of } \\
\text { GDP) }\end{array}$ & $\checkmark$ & & & $\checkmark$ \\
\hline
\end{tabular}




\begin{tabular}{|c|c|c|c|c|c|}
\hline 33. Pension Fund Assets to GDP (\%) & & $\checkmark$ & & $\checkmark$ & \\
\hline $\begin{array}{l}\text { 34. Final Consumption Expenditure, etc in \% of } \\
\text { GDP }\end{array}$ & $\checkmark$ & & $\checkmark$ & $\checkmark$ & $\checkmark$ \\
\hline $\begin{array}{l}\text { 35. Production of Total Construction, Index } \\
2010=100 \text {, Annual, Not Seasonally Adjusted }\end{array}$ & & $\checkmark$ & $\checkmark$ & & $\checkmark$ \\
\hline 36. Total Central Govt. Debt \% of GDP & $\checkmark$ & $\checkmark$ & $\checkmark$ & & $\sqrt{ }$ \\
\hline $\begin{array}{l}\text { 37. Production of Total Industry Index } 2010=100 \text {, } \\
\text { Annual, Not Seasonally Adjusted }\end{array}$ & $\checkmark$ & & $\checkmark$ & $\checkmark$ & $\checkmark$ \\
\hline 38. GDP per Hour Worked $(2010=100)$ & $\checkmark$ & & $\checkmark$ & $\checkmark$ & $\checkmark$ \\
\hline $\begin{array}{l}\text { 39. Labour Productivity per Hour Worked, } \\
\text { Annual Growth Rate }(\%)\end{array}$ & & & & & $\checkmark$ \\
\hline 40. Labour Productivity, Annual Growth Rate (\%) & $\checkmark$ & $\checkmark$ & & & $\checkmark$ \\
\hline 41. Manufacturing, Value Added (\% of GDP) & $\checkmark$ & $\checkmark$ & $\checkmark$ & $\checkmark$ & $\checkmark$ \\
\hline 42. Industry, Value Added ( $\%$ of GDP) & $\checkmark$ & & $\checkmark$ & & $\checkmark$ \\
\hline 43. Agriculture, value added ( $\%$ of GDP) & $\checkmark$ & $\checkmark$ & $\checkmark$ & $\checkmark$ & $\checkmark$ \\
\hline $\begin{array}{l}\text { 44. Total Production of Investment Goods for } \\
\text { Manufacturing for PIIGS, Index 2010=1, Annual, } \\
\text { Not Seasonally Adjusted }\end{array}$ & $\checkmark$ & $\checkmark$ & $\checkmark$ & $\checkmark$ & $\checkmark$ \\
\hline 45. Labour Utilisation Annual Growth Rate & $\checkmark$ & $\checkmark$ & & $\checkmark$ & $\sqrt{ }$ \\
\hline $\begin{array}{l}\text { 46. Unit Labour Costs By Persons Employed, } \\
\text { Percentage Change, Previous Period }\end{array}$ & & & $\checkmark$ & & $\checkmark$ \\
\hline $\begin{array}{l}\text { 47. Unit Labour Costs by Hours Worked, } \\
\text { Percentage Change, Previous Period }\end{array}$ & & & & & $\checkmark$ \\
\hline 48. Gross Fixed Capital Formation (\% of GDP) & & $\checkmark$ & $\checkmark$ & $\checkmark$ & $\checkmark$ \\
\hline $\begin{array}{l}\text { 49. Gross fixed capital formation (annual \% } \\
\text { growth) }\end{array}$ & & $\checkmark$ & & & $\checkmark$ \\
\hline 50. Gross Capital Formation ( $\%$ annual growth) & & $\checkmark$ & & & $\checkmark$ \\
\hline 51. Gross Capital Formation ( $\%$ of GDP) & & $\checkmark$ & $\checkmark$ & $\checkmark$ & $\checkmark$ \\
\hline 52. FDI Net Outflow (in $\%$ of GDP) & & $\checkmark$ & $\checkmark$ & $\checkmark$ & \\
\hline 53. FDI Net Inflow (in \% of GDP) & & & & & $\checkmark$ \\
\hline 54. Net FDI in \% of GDP & & & $\checkmark$ & & \\
\hline \multicolumn{6}{|l|}{ Financial Variables } \\
\hline $\begin{array}{l}\text { 1. Net Investment in Nonfinancial Assets (\% of } \\
\text { GDP) }\end{array}$ & $\checkmark$ & $\checkmark$ & $\checkmark$ & $\checkmark$ & $\checkmark$ \\
\hline 2. Corporate Bond Issuance Volume to GDP (\%) & $\checkmark$ & & $\checkmark$ & $\checkmark$ & $\checkmark$ \\
\hline 3. Total factoring volume to GDP (\%) & & $\checkmark$ & $\checkmark$ & $\checkmark$ & $\checkmark$ \\
\hline 4. Provisions to Nonperforming Loans (\%) & & $\checkmark$ & $\checkmark$ & & \\
\hline 5. Financial System Deposits to GDP (\%) & & $\checkmark$ & & & $\checkmark$ \\
\hline 6. Liquid Liabilities to GDP (\%) & & & $\checkmark$ & & \\
\hline 7. Insurance Company Assets to GDP (\%) & & $\checkmark$ & & $\checkmark$ & \\
\hline 8. Nonlife Insurance Premium Volume to GDP (\%) & & & & $\checkmark$ & $\checkmark$ \\
\hline $\begin{array}{l}\text { 9. Domestic Credit Provided by Financial Sector } \\
(\% \text { of GDP) }\end{array}$ & $\checkmark$ & $\checkmark$ & & $\checkmark$ & $\checkmark$ \\
\hline $\begin{array}{l}\text { 10. Credits to Government and State Owned } \\
\text { Enterprises to GDP (\%) }\end{array}$ & $\checkmark$ & & $\checkmark$ & & $\checkmark$ \\
\hline $\begin{array}{l}\text { 11. Private Credit by Deposit Money Banks and } \\
\text { Other Financial Institutions to GDP (\%) }\end{array}$ & $\checkmark$ & $\checkmark$ & & & $\checkmark$ \\
\hline 12. Stock Price Volatility & $\checkmark$ & & $\checkmark$ & $\checkmark$ & $\checkmark$ \\
\hline 13. Stock Market Capitalization to GDP (\%) & & & & $\checkmark$ & $\checkmark$ \\
\hline
\end{tabular}




\begin{tabular}{|c|c|c|c|c|c|}
\hline 14. Gross Portfolio Debt Assets to GDP (\%) & $\checkmark$ & $\checkmark$ & $\checkmark$ & $\checkmark$ & $\checkmark$ \\
\hline 15. Gross portfolio debt liabilities to GDP (\%) & $\checkmark$ & $\checkmark$ & & $\checkmark$ & $\checkmark$ \\
\hline 16. Gross Portfolio Equity Assets to GDP (\%) & $\checkmark$ & & & $\checkmark$ & \\
\hline 17. Gross Portfolio Equity Liabilities to GDP (\%) & $\checkmark$ & & & $\checkmark$ & \\
\hline $\begin{array}{l}\text { 18. Portfolio Equity, Net Inflows (BoP, in \% of } \\
\text { GDP) }\end{array}$ & & & $\checkmark$ & $\checkmark$ & $\checkmark$ \\
\hline 19. Stock market return (\%, year-on-year) & $\checkmark$ & & & & \\
\hline $\begin{array}{l}\text { 20. Total Share Prices for All Shares Index } 2010=1 \text {, } \\
\text { Annual, Not Seasonally Adjusted }\end{array}$ & $\checkmark$ & $\checkmark$ & & $\checkmark$ & $\checkmark$ \\
\hline $\begin{array}{l}\text { 21. Net Lending }(+) / \text { Net Borrowing }(-) \text { (\% of } \\
\text { GDP) }\end{array}$ & $\checkmark$ & & $\checkmark$ & & $\checkmark$ \\
\hline 22. Immediate Rates: Less than 24 Hours: Call & $\checkmark$ & $\checkmark$ & $\checkmark$ & $\checkmark$ & $\checkmark$ \\
\hline \multicolumn{6}{|l|}{ Money/Interbank Rate in \% } \\
\hline 23. Long-term Interest Rates Total, $\%$ per Annum & & $\checkmark$ & & & \\
\hline 24. Short term Interest Rate (\%per annum) & $\checkmark$ & $\checkmark$ & $\checkmark$ & $\checkmark$ & $\checkmark$ \\
\hline $\begin{array}{l}\text { 25. Outstanding domestic public debt securities to } \\
\text { GDP }(\%)\end{array}$ & & & $\checkmark$ & & $\checkmark$ \\
\hline $\begin{array}{l}\text { 26. Outstanding International Public Debt } \\
\text { Securities to GDP\% Annual, Not Seasonally } \\
\text { Adjusted }\end{array}$ & $\checkmark$ & $\checkmark$ & & $\checkmark$ & $\checkmark$ \\
\hline $\begin{array}{l}\text { 27. Outstanding Domestic Private Debt Securities } \\
\text { to GDP }(\%)\end{array}$ & & $\checkmark$ & $\checkmark$ & & \\
\hline $\begin{array}{l}\text { 28. Outstanding International Private Debt } \\
\text { Securities to GDP Percent, Annual, Not Seasonally } \\
\text { Adjusted }\end{array}$ & $\checkmark$ & & $\checkmark$ & & \\
\hline 29. General Government Debt Total, \% of GDP & $\checkmark$ & & $\checkmark$ & $\checkmark$ & $\sqrt{ }$ \\
\hline \multicolumn{6}{|l|}{ Banking Variables } \\
\hline $\begin{array}{l}\text { 1. Bank Nonperforming Loans to Total Gross } \\
\text { Loans }(\%)\end{array}$ & $\checkmark$ & & $\checkmark$ & $\checkmark$ & \\
\hline 2. Bank Capital to Assets Ratio (\%) & & $\checkmark$ & $\checkmark$ & $\checkmark$ & $\sqrt{ }$ \\
\hline 3. Central Bank Assets to GDP (\%) & & $\checkmark$ & $\checkmark$ & $\checkmark$ & $\checkmark$ \\
\hline $\begin{array}{l}\text { 4. Domestic Credit to Private Sector by Banks (\% } \\
\text { of GDP) }\end{array}$ & $\checkmark$ & $\checkmark$ & $\checkmark$ & $\checkmark$ & $\checkmark$ \\
\hline 5. Loans from Nonresident Banks (net) to GDP (\%) & & $\checkmark$ & & $\checkmark$ & \\
\hline 6. Deposit Money Banks' Assets to GDP (\%) & & $\checkmark$ & & & $\checkmark$ \\
\hline $\begin{array}{l}\text { 7. Bank Credit to Bank Deposits Percent, Annual, } \\
\text { Not Seasonally Adjusted }\end{array}$ & & $\checkmark$ & & & $\checkmark$ \\
\hline $\begin{array}{l}\text { 8. Bank's Cost to Income Ratio, Percent, Annual, } \\
\text { Not Seasonally Adjusted }\end{array}$ & & $\checkmark$ & & & $\checkmark$ \\
\hline $\begin{array}{l}\text { 9. 3-Month or 90-day Rates and Yields: Interbank } \\
\text { Rates Percent, Annual, Not Seasonally Adjusted }\end{array}$ & $\checkmark$ & $\checkmark$ & $\checkmark$ & $\checkmark$ & $\checkmark$ \\
\hline \multicolumn{6}{|l|}{ Social Variables } \\
\hline $\begin{array}{l}\text { 1. Political Stability and Absence of Violence/ } \\
\text { Terrorism }\end{array}$ & $\checkmark$ & & & $\checkmark$ & $\checkmark$ \\
\hline 2. Governance Effectiveness & $\checkmark$ & & $\checkmark$ & & $\sqrt{ }$ \\
\hline 3. Regulator Quality & $\checkmark$ & & & & $\checkmark$ \\
\hline 4. Rule of Law & $\checkmark$ & $\checkmark$ & $\checkmark$ & $\checkmark$ & $\checkmark$ \\
\hline 5. Control of Corruption & & & & & $\checkmark$ \\
\hline $\begin{array}{l}\text { 6. Unemployment, Total (\% of Total Labor Force) } \\
\text { (modeled ILO estimate) }\end{array}$ & & $\checkmark$ & $\checkmark$ & $\checkmark$ & $\checkmark$ \\
\hline
\end{tabular}




\begin{tabular}{|l|l|l|l|l|l|}
\hline 7. Birth Rate, Crude (per 1,000 people) & $\checkmark$ & $\checkmark$ & $\checkmark$ & $\checkmark$ & $\checkmark$ \\
\hline 8. Death Rate, Crude (per 1,000 people) & $\checkmark$ & $\checkmark$ & & $\checkmark$ & $\checkmark$ \\
\hline $\begin{array}{l}\text { 9. Age Dependency Ratio (\% of working-age } \\
\text { population) }\end{array}$ & $\checkmark$ & $\checkmark$ & $\checkmark$ & $\checkmark$ & $\checkmark$ \\
\hline 10. Age Dependency Ratio, Old & $\checkmark$ & $\checkmark$ & $\checkmark$ & $\checkmark$ & $\checkmark$ \\
\hline 11. Age Dependency Ratio, Young & $\checkmark$ & $\checkmark$ & $\checkmark$ & $\checkmark$ & $\checkmark$ \\
\hline $\begin{array}{l}\text { 12. Labor Force with Advanced Education (\% of } \\
\text { total) }\end{array}$ & & & $\checkmark$ & $\checkmark$ & \\
\hline 13. Labor Force with Basic Education (\% of total) & $\checkmark$ & & $\checkmark$ & & \\
\hline 14. Rural Population (\% of total population) & $\checkmark$ & $\checkmark$ & $\checkmark$ & $\checkmark$ & $\checkmark$ \\
\hline
\end{tabular}

Source: Based on Author's Calculation

\section{CONCLUSION}

The main exquisiteness of this paper is getting the effect of the crisis with the help of the structural break analysis for the medium run by using annual data. The logic behind this is that if variables are statistically significantly affected by the crisis then they will surely come out to represent the effect of the crisis even in the medium span of phenomenon. This euro-zone crisis is happened in the aftermath of the US sub-prime crisis, which has triggered the global market in second half of the 2007. After analyzing 113 different Variables 106 Variables found to be significant variables at $10 \%$ level of significance, which were affected by the crisis in different PIIGS nations. The structural breaks were found in trend-line of these 106 Variables during crisis period (2008-09) and post crisis period (20102015). The most affected country among PIIGS nations is Spain with 87 significant variables and the least affected country is Ireland with 67 significant variables. Spain is the most affected country among PIIGS nations both during the crisis and after the crisis. The least affected country in the post crisis period is either Ireland or Italy.

If economic recovery within this frame of crisis window is examined, it is found Spain has started late recovery from first wave of originating recession (2008-09) as compared to other PIIGS nations. If the general meaning of recession is taken as the negative economic growth for two continuous quarters or more $^{2}$ Italy started recovery in third quarter of 2009; whereas Portugal, Ireland and Greece started recovery in second quarter of 2009. All these PIIGS nations except Spain have commenced recovery also within this crisis period 2008-09. But it is clear form the figures of quarterly GDP growth that Spain has not shown any sign of recovery during 2008-09 and over this period of two years or eight quarters Spain has faced recession for six consecutive quarters as compared to four consecutive quarters in Portugal, Greece and five consecutive quarters in Italy and Ireland. As per Donal Donovan (2017) Ireland recovered fast in post crisis period as a result of IF continuous effort inclined to macroeconomic stabilization programme in Ireland. Spain recovered late due to bureaucracy and lack of political consensus.

\section{REFERENCES}

1) Dullien, S. (2010). Risk Factors in International Financial Crises: Early Lessons from the 20082009 Turmoil . In D. J. Sebastian Dullien (Ed.), The Financial and Economic Crisis in 2008-2009 and Developing Countries. New York and Geneva: United Nations.

2) Donovan, D. (2017). The IMF's Role in Ireland. In M. J. Takagi (Ed.), Background Papers for The

2. As per Economic Information newsletter February 2009. 
IMF and the Crises in Greece, Ireland, and Portugal (pp. 319-362). USA.

3) Dionisis Chionis, I. P. (2016). The determinants of Greek bond yields: an empirical study before and during the crisis. Journal of Economic Studies, 43 (3), 504-519.

4) FitzGerald, J. (2014). Ireland's Recovery from Crisis. CESifo Forum, 15 (No. 2), 8-13.

5) Gavron, D. C. (2004). Channels of financial market contagion. Applied Economics, 36 (21), 2461-2469.

6) James R. Barth, A. (2012). The eurozone financial crisis: role of interdependencies between bank and sovereign risk. Journal of Financial Economic Policy, 4 (1), 76-97.

7) Kretsos, L. (2011). Grassroots unionism in the context of economic crisis in Greece . Labor History, 52 (3), 265-286.

8) Kousis, J. N. (2013). Economic Crisis, Troika and the Environment in Greece . South European Society and Politics, 18 (3), 305-331.

9) KarlWhelan. (2014). Ireland's Economic Crisis The Good, the Bad and the Ugly. (T. P. Heather D. Gibson, Ed.) Journal of Macroeconomics, 39 (Part B), 424-440.

10) Mugarura, N. (2016). Law as an equalizer: "Contemporary global crises" and its implication on the global village. International Journal of Law and Management, 58 (6), 602-617.

11) Meunier, L. G. (2013). Time Will Tell: The EFSF, the ESM, and the Euro Crisis. Journal of European Integration, 35 (3), 239-253.

12) Mcdonald, H. (2013, December 13). Ireland becomes first country to exit eurozone bailout programme. The Guardian.

13) Nadia Garbellini, E. M. (2014). Domestic demand and global production in the Eurozone: A multiregional input-output assessment of the global crisis. International Review of Applied Economics, 28 (3), 336-364.

14) Onaran, E. S. (2012). Rethinking wage policy in the face of the Euro crisis. Implications of the wage-led demand regime. International Review of Applied Economics, 26 (2), 191-203.

15) Prorokowski, L. (2011). Recovery from the current banking crisis: Insights into costs and effectiveness of response regulations. Qualitative Research in Financial Markets, 3 (3), 193-223.

16) Pühringer, S. (2015). Markets as "ultimate judges" of economic policies: Angela Merkel's discourse profile during the economic crisis and the European crisis policies. On the Horizon, 23 (3), 246-259.

17) Rapanos, G. K. (2012). Tax and Trust: The Fiscal Crisis in Greece . South European Society and Politics, 18 (3), 283-304.

18) Rossi, L. C.-P. (2015). Sovereignty, the exchange rate, collective deceit, and the euro crisis. Journal of Post Keynesian Economics, 38 (3), 355-375.

19) Santiago Carbó-Valverde, H. A. (2015). Regulatory response to the financial crisis in Europe: recent developments (2010-2013). Journal of Financial Economic Policy, 7 (1), 29-50.

20) Smith, D. C. (2009). What Is a Recession? Research Library. Federal Reserve Bank of St. Louis.

21) Tracy, J. F. (2011). Covering "Financial Terrorism" The Greek debt crisis in US news media. Journalism Practice, 6 (4), 513-529.

22) Valerio Filoso, V. a. (2016). Causes and timing of the European debt crisis: An econometric evaluation. (Paper No. 75847).

23) Vlamis, P. (2013). Greek Fiscal Crisis and Repercussions for the Property Market. Hellenic Observatory Papers on Greece and Southeast Europe, GreeSE Paper No. 76.

24) Wasim Ahmad, N. B. (2014). The Eurozone crisis and its contagion effects on the European stock markets. Studies in Economics and Finance, 31 (3), 325-352. 